\title{
PENINGKATAN PEMASARAN BIDUK WISATA NELAYAN DI SUNGAI PISANG, BUNGUS TELUK KABUNG SELATAN, SUMATERA BARAT
}

\author{
Elita Amrina*), Insannul Kamil, dan Hadigufri Triha \\ Jurusan Teknik Industri Fakultas Teknik Universitas Andalas \\ ${ }^{*}$ Email: elita@eng.unand.ac.id
}

\begin{abstract}
ABSTRAK
Kondisi geografis Kelurahan Sungai Pisang yang terletak di pinggiran pantai dan tidak terlalu jauh dari potensi wisata pulau yang terkenal di Sumatera Barat menjadi peluang bagi masyarakat Sungai Pisang khususnya nelayan biduk untuk meningkatan taraf hidupnya. Namun kenyataannya, pihak luar yang berada di daerah Bungus justru yang lebih memanfaatkan peluang tersebut karena lokasinya yang dekat dengan pusat kota. Wisatawan yang ramai hanya bisa dilihat dari jauh oleh nelayan biduk Sungai Pisang ini. Kebanyakan wisatawan lebih memilih untuk menggunakan jasa Tour and Travel dari Bungus. Nelayan biduk hanya membawa sedikit wisatawan saja menuju wisata pulau walaupun harga yang ditawarkan jauh lebih murah. Berdasarkan analisis situasi, permasalahan tersebut terjadi karena kurangnya pengetahuan nelayan biduk tentang strategi pemasaran produk yang efektif. Selain itu, biduk yang digunakan masih sangat sederhana, belum memperhatikan aspek keselamatan dan kenyamanan penupang. Sejauh ini belum adanya sarana pemasaran produk untuk mempromosikan jasa transportasi biduk wisata pulau dari nelayan biduk di Sungai Pisang secara luas. Kegiatan ini bertujuan untuk memberikan pengetahuan dan penjelasan kepada nelayan biduk mengenai strategi pemasaran produk yang efektif untuk meningkatkan jumlah wisatawan pengguna biduk wisata pulau, merancang desain biduk yang menarik dan melengkapi biduk dengan fasilitas keselamatan dan kenyamanan penumpang untuk meningkatkan kepuasan wisatawan terhadap jasa transportasi biduk, merancang dan membuat media promosi berupa website pemasaran biduk yang dihubungkan dengan berbagai media sosial untuk memperkenalkan secara luas biduk wisata pulau di Sungai Pisang, dan memberikan pengetahuan dan keterampilan kepada nelayan biduk dalam menggunakan dan mengelola website sehingga dapat digunakan secara berkelanjutan.
\end{abstract}

Kata Kunci: nelayan biduk, pemasaran, website, wisata pulau

\section{Peningkatan Pemasaran Biduk Wisata Nelayan Di Sungai Pisang, Bungus Teluk Kabung Selatan, Sumatera Barat}

\begin{abstract}
The geographical of Sungai Pisang Village, which is located on the coast and not too far from the famous tourism potential of the island in West Sumatra, is an opportunity for the people of the Sungai Pisang, especially the biduk fishermen to improve their standard of living. But in reality, the outsiders in the Bungus area took advantage of the opportunity because of its location close to the city center. Many tourists can only be seen from afar by the Sungai Pisang fishermen. Most tourists prefer to use the services of Tour and Travel from Bungus. Biduk fishermen only bring a few tourists to the island tour even though the price offered is much cheaper. Based on the situation analysis, these problems occur because of the lack of knowledge of the fishermen on the effective product marketing strategies. In addition, the biduk used is still very simple, not paying attention to the safety and comfort aspects of the occupants. So far there has been no product marketing tools to promote the tourism transportation services of island tourists from fishermen on the Sungai Pisang widely. This activity aims to provide knowledge and explanation to biduk fishermen regarding the effective product marketing strategies to increase the number of tourists who use island tours, developing a biduk design that is attractive and facilitate with passenger safety and comfort facilities to increase tourist satisfaction with biduk transportation services, designing and creating promotional media in the form of marketing websites that are linked to various social media to widely introduce biduk island tourism in Sungai Pisang, and provide knowledge and skills to biduk fishermen in using and managing websites so that they can be used
\end{abstract}


sustainably.

Keywords: biduk fishermen, marketing, website, island tour

\section{PENDAHULUAN}

Sungai Pisang merupakan sebuah kelurahan yang terletak di Kecamatan Bungus Teluk Kabung Selatan, Kota Padang, Provinsi Sumatera Barat. Luas Kelurahan Sungai Pisang yaitu $9,14 \mathrm{~km}^{2}$ dengan jumlah penduduk sebanyak 1914 jiwa dan total jumlah kepala keluarga (KK) sebanyak 314 KK. Hampir seluruh KK memiliki mata pencaharian sebagai nelayan karena letak geografisnya berada di pinggiran pantai. Profesi sebagai nelayan sangat bergantung pada hasil tangkapan ikan untuk memenuhi kebutuhan hidup dan jika ada sisa dari penghasilan tersebut akan digunakan untuk biaya memenuhi kebutuhan sandang dan biaya pendidikan (Wasak, 2012). Hasil tangkapan ikan yang dijual akan dipergunakan dan langsung habis, sehingga tidak ada simpanan untuk pengembangan usaha (Sudarso, 2003). Apabila nelayan hanya mengandalkan perahu tradisional dan alat tangkap ikan sederhana, maka nelayan tersebut tidak akan mampu bersaing dengan nelayan modern yang memiliki perlengkapan dan fasilitas yang lebih canggih (Sarjulis, 2011).

Selain sebagai nelayan yang normalnya mencari ikan di laut, maka nelayan didaerah Sungai Pisang juga menggunakan biduknya untuk mengangkut wisatawan menuju wisata pulau yang terletak tidak jauh dari Kelurahan Sungai Pisang. Masyarakat Sungai Pisang tergolong masyarakat yang berkeinginan untuk berkembang dan menerima dinamika kehidupan yang timbul sebagai dampak dari globalisasi. Masyarakat Sungai Pisang merupakan masyarakat yang taat beragama, ramah tamah, dan santun. Sehingga, wisatawan yang menuju pulau dan menggunakan jasa transportasi biduk wisata pulau merasa nyaman dan terkesan dengan pelayanan yang diberikan.

Kondisi geografis Kelurahan Sungai Pisang yang terletak di pinggiran pantai dan tidak terlalu jauh dari potensi wisata pulau yang terkenal di Sumatera Barat, menjadi peluang bagi masyarakat Sungai Pisang khususnya nelayan biduk untuk meningkatan taraf hidupnya. Pariwisata merupakan salah satu industri yang mampu menyediakan pertumbuhan ekonomi yang cepat dalam hal penyediaan lapangan kerja, pendapatan, tarif hidup, dan dalam mengaktifkan sektor produksi lain di dalam negara penerima wisatawan (Sari, 2011). Wisata pulau sekarang ini menjadi objek pariwisata yang populer di Sumatera Barat. Untuk menikmati wisata pulau dibutuhkan jasa transportasi yang membawa wisatawan dari daratan menuju pulau yang dimaksud. Jasa transportasi biduk wisata pulau disediakan oleh masyarakat Sungai Pisang sebagai mata pencaharian selain sebagai nelayan di malam hari. Setiap kepala keluarga di Sungai Pisang biasanya memiliki satu biduk untuk membawa wisatawan ke berbagai wisata pulau yang berada di sekitar Sungai Pisang. Terdapat 4 tujuan wisata pulau yang dapat dijadikan sebagai destinasi pengguna jasa transportasi biduk wisata pulau di Sungai Pisang, yaitu Pulau Pasumpahan, Pulau Pamutusan, Pulau Pagang, dan Suwarnadwipa.

Pulau Pasumpahan terletak tidak terlalu jauh dari Sungai Pisang, sehingga apabila nelayan biduk membawa wisatawan menuju Pulau Pasumpahan hanya membutuhkan waktu selama 10 menit. Wisatawan yang menuju Pulau Pasumpahan dikenakan tarif Rp 35.000 ,- perorang. Untuk tujuan wisata Pulau Pamutusan, memerlukan waktu selama 25 
menit. Wisatawan yang menuju Pulau Pamutusan dikenakan tarif Rp 50.000,- perorang. Tujuan wisata pulau yang tidak kalah menarik berikutnya yaitu Pulau Pagang, dimana untuk mencapai pulau tersebut membutuhkan waktu selama 30 menit. Wisatawan yang ingin ke Pulau Pagang dikenakan tarif sebesar Rp 60.000,- perorang. Tarif tersebut merupakan tarif tertinggi dibanding wisata pulau lainnya, karena selain letaknya yang jauh juga karena wisata Pulau Pagang memilikipeminat yang tinggi karena keindahan pulaunya.

Wisata pulau lainnya yaitu Suwarnadwipa dimana Suwarnadwipa sebenarnya bukan termasuk jenis pulau, namun merupakan daratan Sumatera yang letaknya di sekitar pulau-pulau kecil dan hanya bisa diakses dengan transportasi laut. Untuk mencapai Suwarnadwipa, maka wisatawan dikenakan tarif Rp 50.000,- perorang dengan lama perjalanan sekitar 25 menit. Untuk ketiga jenis wisata pulau sebagai destinasi wisatawan seperti Pulau Pasumpahan, Pulau Pamutusan, dan Pulau Pagang, pihak pengelola pulau tidak memberikan retribusi kepada pihak nelayan biduk atas wisatawan yang dibawa ke pulau tersebut, sehingga penghasilan yang diperoleh nelayan biduk hanya berasal dari tarif biduk yang dikenakan perorang wisatawan. Namun untuk wisata Suwarnadwipa, pihak pengelola memberikan retribusi kepada nelayan biduk yang telah membawa wisatawansebanyak Rp 5.000,- perorang.

Namun kenyataannya peluangdari wisata pulau tersebut tidak dapat memberi keuntungan bagi masyarakat Sungai Pisang. Pihak luar yang berada di daerah Bungus justru yang lebih memanfaatkan peluang tersebut karena lokasinya yang lebih dekat dengan pusat kota. Disana banyak terdapat Tour and Travel yang menyediakan wisata pulau dengan paket-paket yang menarik dengan harga berkisar Rp. 250.000,- hingga Rp. 350.000,-. Lokasi daerah Bungus yang dekat dengan kota membuat wisatawan lebih banyak memilih untuk berangkat menuju wisata pulau dari Bungus dengan menggunakan jasa Tour and Travel. Hal tersebut tentu merugikan masyarakat nelayan biduk di Sungai Pisang.

Nelayan tradisional seharusnya dapat menggunakan peluang wisata pulau tersebut dengan menjadi nelayan biduk yang membawa wisatawan ke pulau yang berada tidak jauh dari Kelurahan Sungai Pisang. Namun, harapan tentunya tidak selalu sesuai dengan kenyataan, kebanyakan dari nelayan biduk Kelurahan Sungai Pisang hanya bisa "gigit jari" dengan peluang emas tersebut. Wisatawan dari wisata pulau yang ramai hanya bisa dilihat dari jauh oleh nelayan biduk Sungai Pisang ini. Kebanyakan wisatawan lebih memilih untuk menggunakan jasa Tour and Travel dari Bungus. Kenyataannya nelayan biduk hanya membawa sedikit wisatawan saja menuju wisata pulau. Padahal harga yang ditawarkan jauh lebih murah.

Menurut penuturan beberapa nelayan biduk di Sungai Pisang, hingga sekarang belum ada peran dan bantuan dari pemerintah setempat untuk perkembangan usaha jasa transportasi biduk yang dimiliki nelayan biduk tersebut. Berdasarkan pengamatan dilokasi, masyarakat setempat khususnya nelayan biduk belum memiliki pengetahuan yang baik tentang strategi pemasaran produk. Mereka tidak dapat berbuat banyak ketika usaha Tour and Travel di Bungus semakin meningkat sedangkan penghasilan mereka dari usaha nelayan biduk dari hari kehari semakin berkurang. Usaha yang selama ini dilakukan oleh para nelayan biduk untuk mendapatkan wisatawan adalah dengan berkenalan dengan para wisatawan yang pernah menggunakan jasa biduk mereka dan memberikan nomor telepon yang bisa dihubungi. Selanjutnya nelayan biduk meminta supaya wisatawan tersebut akan menggunakan kembali jasa biduk mereka dengan 
menghubungi nomor tersebut dan juga untuk mempromosikan biduk mereka kepada yang keluarga, kenalan, teman yang nanti akan melakukan wisata pulau atau yang sering disebut dengan strategi dari mulut ke mulut (word of mouth). Strategi ini cepat diterima sebagai referensi karena pengguna biasanya sulit mengevaluasi jasa yang belum dirasakannya sendiri (Lovelock dan Wirtz, 2011). Tetapi usaha ini belum membuahkan hasil yang memuaskan. Terkadang dalam satu hari tidak ada penumpang yang diangkut sama sekali.

Usaha nelayan biduk yang dilakoni oleh masyarakat Sungai Pisang masih berupa usaha skala kecil. Berdasarkan pengamatan, hanya sedikit biduk yang memiliki nama. Sebagian besar belum memiliki nama untuk biduk mereka. Hal ini tentu menyulitkan wisatawan untuk mengenali biduk yang akan digunakan sebagai jasa transportasi wisata pulau. Selain itu juga terdapat kekurangan dalam perlengkapan keselamatan biduk dimana yang tersedia hanya beberapa baju pelampung saja dan jarang digunakan penumpang. Biduk juga tidak dilengkapi dengan perlengkapan lain untuk keperluan wisata pulau seperti perlengkapan snorkeling.

Selain kondisi-kondisi diatas, minimnya jumlah wisatawan juga juga diperparah dengan kondisi jalan dari jalan lalu lintas utama menuju daerah Sungai Pisang yang buruk (tidak beraspal dan banyak berlubang), sehingga wisatawan kesulitan untuk mencapai daerah Sungai Pisang dengan menggunakan transportasi pribadi. Selain itu, tidak adanya transportasi umum yang tersedia baik itu berupa angkutan desa maupun ojek untuk pengangkutan ke daerah Sungai Pisang. Hal tersebut memicu minimnya jumlah wisatawan yang datang ke Sungai Pisang untuk menggunakan jasa transportasi biduk wisata pulau dari nelayan biduk di Sungai Pisang. Sementara jalan menuju daerah Bungus terdapat jalan yang baik dan tersedia angkutan umum yang memadai.

Berdasarkan analisis situasi diatas maka prioritas permasalahan yang diselesaikan pada kegiatan ini adalah:

1. Kurangnya pengetahuan tentang strategi pemasaran produk yang efektif sehingga mengakibatkan rendahnya jumlah wisatawan yang menggunakan jasa transportasi biduk wisata pulau dari nelayan biduk di Sungai Pisang.

2. Biduk yang digunakan masih sangat sederhana, belum memperhatikan aspek keselamatan dan kenyamanan penupang sehingga masih kurang diminati oleh wisatawan untuk wisata pulau dari Sungai Pisang.

3. Belum adanya sarana pemasaran produk yang lebih baik sehingga jasa transportasi biduk wisata pulau dari nelayan biduk di Sungai Pisang dapat lebih dikenal secara luas.

Solusi yang ditawarkan untuk menyelesaikan permasalahan prioritas yang dihadapi adalah sebagai berikut:

1. Memberikan pengetahuan kepada nelayan biduk mengenai strategi pemasaran produk yang efektif untuk meningkatkan jumlah wisatawan pengguna jasa transportasi wisata pulau di Pulau Pisang.

2. Merancang desain biduk yang menarik dan melengkapi biduk dengan fasilitas keselamatan dan kenyamanan penumpang sebagai upaya untuk meningkatkan kepuasan wisatawan terhadap jasa transportasi biduk.

3. Merancang dan membuat media promosi berupa website pemasaran biduk yang dihubungkan dengan berbagai media sosial sebagai upaya memperkenalkan secara luas biduk wisata pulau di Pulau Pisang. 
4. Memberikan pengetahuan dan keterampilan kepada nelayan biduk dalam menggunakan dan mengelola website yang telah dibuat sebagai upaya peningkatan perekonomian nelayan biduk yang berkelanjutan.

\section{METODE}

Metode pelaksanaan kegiatan ini terdiri dari penyuluhan strategi pemasaran produk, perancangan desain dan fasilitas biduk, perancangan dan pembuatan website pemasaran biduk, serta pelatihan penggunaan dan pengelolaan website.

\section{Penyuluhan Strategi Pemasaran Produk}

Strategi pemasaran merupakan suatu cara yang digunakan perusahaan dalam memasarkan poduk atau jasa yang dimilikinya. Strategi digunakan untuk meningkatkan daya tarik dari produk dan jasa yang ditawarkan agar mampu bersaing di pasaran. Strategi pemasaran yang biasa dilakukan adalah Segmenting (S), Targeting (T), dan Positioning (P) (Kotler dan Keller, 2009). Segmenting merupakan strategi pemasaran yang dilakukan dalam mengelompokkan pasar yang dituju terhadap produk atau jasa yang dimiliki. Targeting merupakan strategi pemasaran dalam memilih target pasar yang telah dikelompokkan sebelumnya. Sedangkan positioning merupakan strategi pemasaran yang dilakukan dengan cara menarik hati konsumen dengan berbagai cara yang dilakukan, sehingga produk dan jasa yang ditawarkan laku di pasaran.

Selain itu juga dikenal konsep 4P yaitu Product, Price, Place, dan Promotion dalam strategi pemasaran (Kotler dan Keller, 2009). Pertama-tama untuk masuk ke pasar harus memiliki produk yang bagus sesuai dengan target pasar. Produk tersebut harus memiliki harga yang sesuai dengan target pasar. Lokasi atau tempat yang akan dimasuki juga menetukan keberhasilan menggarap target pasar. Terakhir, ketiga $\mathrm{P}$ yang lain tidak akan berarti tanpa promosi, yaitu mengkomunikasikan produk kepada target pasar. Dengan strategi pemasaran yang efektif diharapkan mampu meningkatkan daya tarik wisatawan dalam menggunakan jasa transportasi biduk wisata pulau di Pulau Pisang.

\section{Perancangan Desain dan Fasilitas Biduk}

Perancangan desain biduk mitra agar lebih menarik dilakukan dengan memperhatikan fungsi utama biduk untuk mengangkut wisatawan. Penentuan fitur-fitur rancangan mengikuti kriteria dimensi kualitas menurut Garvin (1988) adalah performansi, daya tahan, keandalan, kemudahan pelayanan, kualitas yang diharapkan, kinerja, dan estetika. Desain biduk disesuaikan dengan bentuk dan ukuran biduk yang dimiliki mitra sekarang. Kenyamanan penumpang biduk sangat diutamakan dalam perancangan desain biduk ini. Perancangan desain biduk dilakukan dengan menggunakan software SolidWork yang terdapat di Laboratorium Sistem Informasi dan Komputasi, Universitas Andalas. Setelah tahap perancangan selesai, dilakukan tahap pembuatan desain pada biduk mitra di Sungai Pisang.

Biduk mitra juga akan dilengkapi dengan peralatan menjaga keamanan penumpang yang sesuai seperti baju pelampung yang bertujuan untuk keselamatan penumpang selama berada di atas biduk mitra.Selain itu biduk juga dilengkapi dengan perlengkapan wisata pulau untuk snorkeling sehingga wisatawan yang ingin menikmati keindahan 
bawah laut dapat menggunakannya tanpa harus menunggu untuk sampai di wisata pulau tujuan. Pembuatan desain dan kelengkapan fasilitas biduk tersebut akan menambah daya tarik jasa transportasi biduk wisata pulau yang dimiliki oleh mitra.

\section{Perancangan dan Pembuatan Website Pemasaran Biduk}

Website pemasaran biduk dirancang di Laboratorium Sistem Informasi dan Komputasi, Universitas Andalas dengan menggunakan bahasa pemrograman PHP dan didukung database MySQL serta pemodelan menggunakan UML. Adapun tahapantahapan dalam kegiatan ini adalah:

1) Tahapan Analisis Kebutuhan

Analisis kebutuhan merupakan tahap mempelajari dan mengkaji sistem yaitu bagaimana pemasaran dan promosi yang efektif untuk biduk wisata pulau di Pulau Pisang. Pada tahapan ini juga dilakukan pengumpulan data dan informasi yang diperlukan untuk digunakan sebagai dasar perancanganwebsite seperti spesifikasi biduk, fasilitas biduk, tarif biduk, tujuan wisata pulau, paket wisata, dan jadwal perjalanan. Analisis kebutuhan yang dilakukan pelaksana kegiatan berupa studi lapangan (observasi), pengumpulan data dan informasi terkait perancangan website pemasaran biduk.

2) Tahapan Perancangan Sistem Database

Berdasarkan data dan informasi yang dikumpulkan, pada tahapan ini akan dirancang suatu sistem database dengan menggunakan MySQL yang menyimpan semua data dan informasi yang diperlukan dalam perancangan website pemasaran biduk. Database ini akan dihubungkan dengan website sehingga memudahkan untuk penyimpanan data dan pengambilan kembali data yang diperlukan.

3) Tahapan Perancangan Website

Tahapan ini merupakan tahapan utama dalam kegiatan ini. Setelah perancangan sistem database selesai, pada tahapan ini akan dirancang website pemasaran biduk dengan menggunakan bahasa pemrograman PHP.

4) Tahapan Validasi

Setelah perancangan website pemasaran biduk selesai, maka perlu divalidasi terlebih dahulu sebelum website ini digunakan. Tahapan validasi merupakan tahapan uji coba website kepada pengguna sistem. Tujuannya untuk mengetahui apakah website yang dirancang telah sesuai dengan kebutuhan mitra dan memberikan output yang diinginkan.

5) Tahapan Instalasi

Pada tahapan ini dilakukan instalasi website pemasaran biduk yang telah dirancang untuk dapat digunakan oleh mitra.

\section{Pelatihan Penggunaan dan Pengelolaan Website}

Setelah dilakukan instalasi website pemasaran biduk kepada mitra, maka selanjutnya dilakukan pelatihan untuk menjelaskan bagaimana penggunaan website tersebut sehingga mitra dapat menggunakan website dengan baik. Selain itu juga 
diberikan pelatihan tentang pengelolaan website sehingga mitra dapat memanfaatkan website pemasaran biduk tersebut secara berkelanjutan.

\section{HASIL DAN PEMBAHASAN}

\section{Penyuluhan Strategi Pemasaran Produk Kepada Nelayan Biduk di Sungai Pisang}

Penyuluhan strategi pemasaran dilakukan untuk meningkatkan pengetahuan nelayan biduk tentang strategi pemasaran yang efektif untuk jasa transportasi biduk wisata pulau di Pulau Pisang. Peserta penyuluhan diberikan pengetahuan tentang strategi pemasaran yang berkaitan dengan konsep Segmenting (S), Targeting (T), dan Positioning (P). Selain itu juga diberikan tentang konsep 4P yaitu Product, Price, Place, dan Promotion dalam strategi pemasaran. Melalui penyuluhan ini diharapkan nelayan biduk dapat memperluas jaringan dan meningkatkan upaya promosi jasa transportasi biduk wisata pulau yang mereka miliki. Dengan menggunakan strategi pemasaran yang efektif, nelayan biduk diharapkan mampu meningkatkan daya tarik wisatawan dalam menggunakan jasa transportasi biduk wisata pulau di Pulau Pisang.

\section{Perancangan Desain dan Peningkatan Fasilitas Biduk Mitra}

Perancangan desain biduk mitra dilakukan supaya biduk menjadi lebih menarik sehingga meningkatkan kenyamanan dan kepuasan penumpang. Perancangan desain biduk memperhatikan aspek performansi, daya tahan, keandalan, kemudahan pelayanan, kualitas, kinerja, dan estetika. Desain biduk disesuaikan dengan bentuk dan ukuran biduk yang dimiliki mitra sekarang. Hasil perancangan kemudian diimplementasikan untuk peningkatan kualitas biduk mitra.

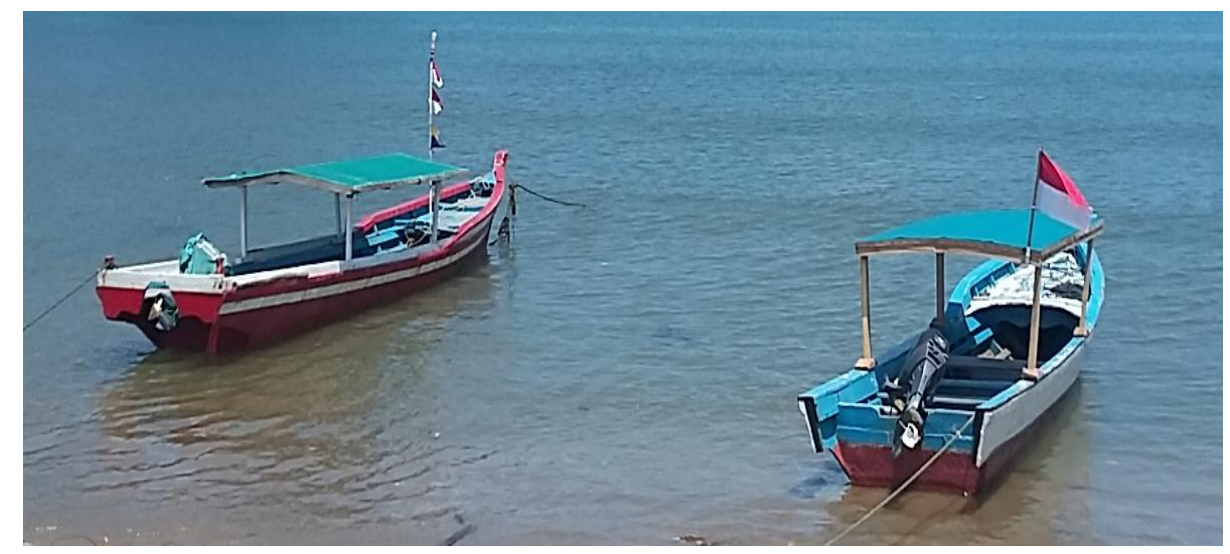

Gambar 1. Biduk Mitra Sebelum Peningkatan 

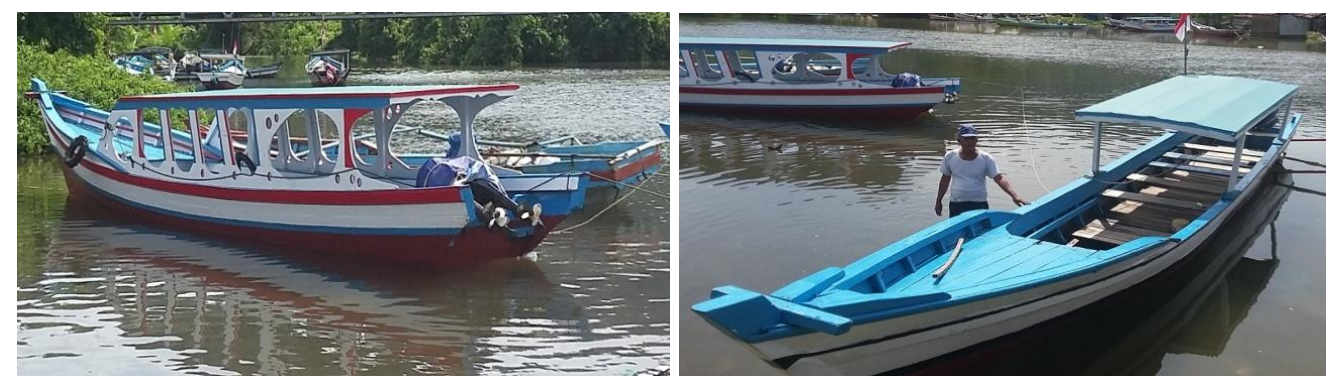

Gambar 2. Biduk Mitra Setelah Peningkatan

Selain itu, fasilitas biduk mitra juga dilengkapi dengan peralatan untuk keamanan penumpang yaitu baju pelampung yang bertujuan untuk keselamatan penumpang selama berada di atas biduk mitra. Biduk juga dilengkapi dengan perlengkapan wisata pulau untuk snorkeling sehingga wisatawan yang ingin menikmati keindahan bawah laut dapat menggunakannya tanpa harus menunggu untuk sampai di wisata pulau tujuan. Peningkatan fasilitas biduk tersebut menambah daya tarik jasa transportasi biduk wisata pulau yang dimiliki oleh mitra. Pelatihan juga diberikan tentang pemakaian pelampung dan penggunaan snorkeling.
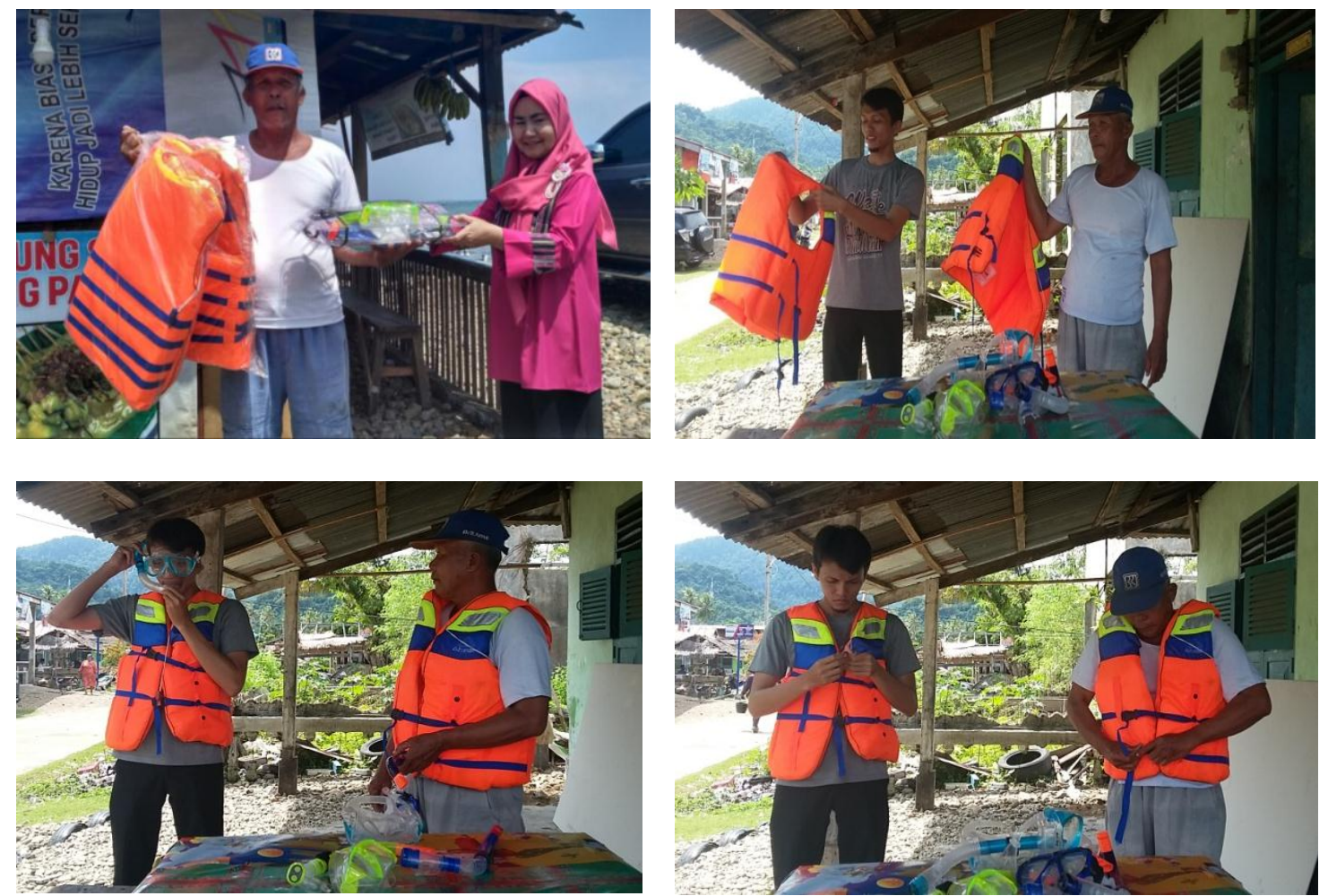

Gambar 3. Kegiatan Penyerahan Pelampung dan Snorkeling dan Pelatihan Penggunaannya

Berdasarkan wawancara dengan mitra, setelah peningkatan kualitas biduk dan penambahan perlengkapan pelampung dan snorkeling pada biduk mitra, terjadi peningkatan jumlah wisatawan yang menggunakan jasa biduk wisata pulau mitra. Wisatawan merasa lebih nyaman dan aman dengan biduk mitra yang sekarang. 
Keamanan menjadi salah satu faktor pertimbangan wisatawan dalam memilih biduk wisata pulau. Penyediaan snorkeling juga menjadi nilai tambah bagi biduk mitra dalam meningkatkan kepuasan wisatawan. Dapat disimpulkan bahwa peningkatan fasilitas ini mampu meningkatkan penghasilan nelayan biduk.

\section{Perancangan Website Pemasaran Biduk Mitra}

Website pemasaran biduk nelayan Sungai Pisang dirancang berupa webmobile yang dapat diaktifkan melalui komputer maupun smartphone. Berikut adalah tampilan website yang dirancang.

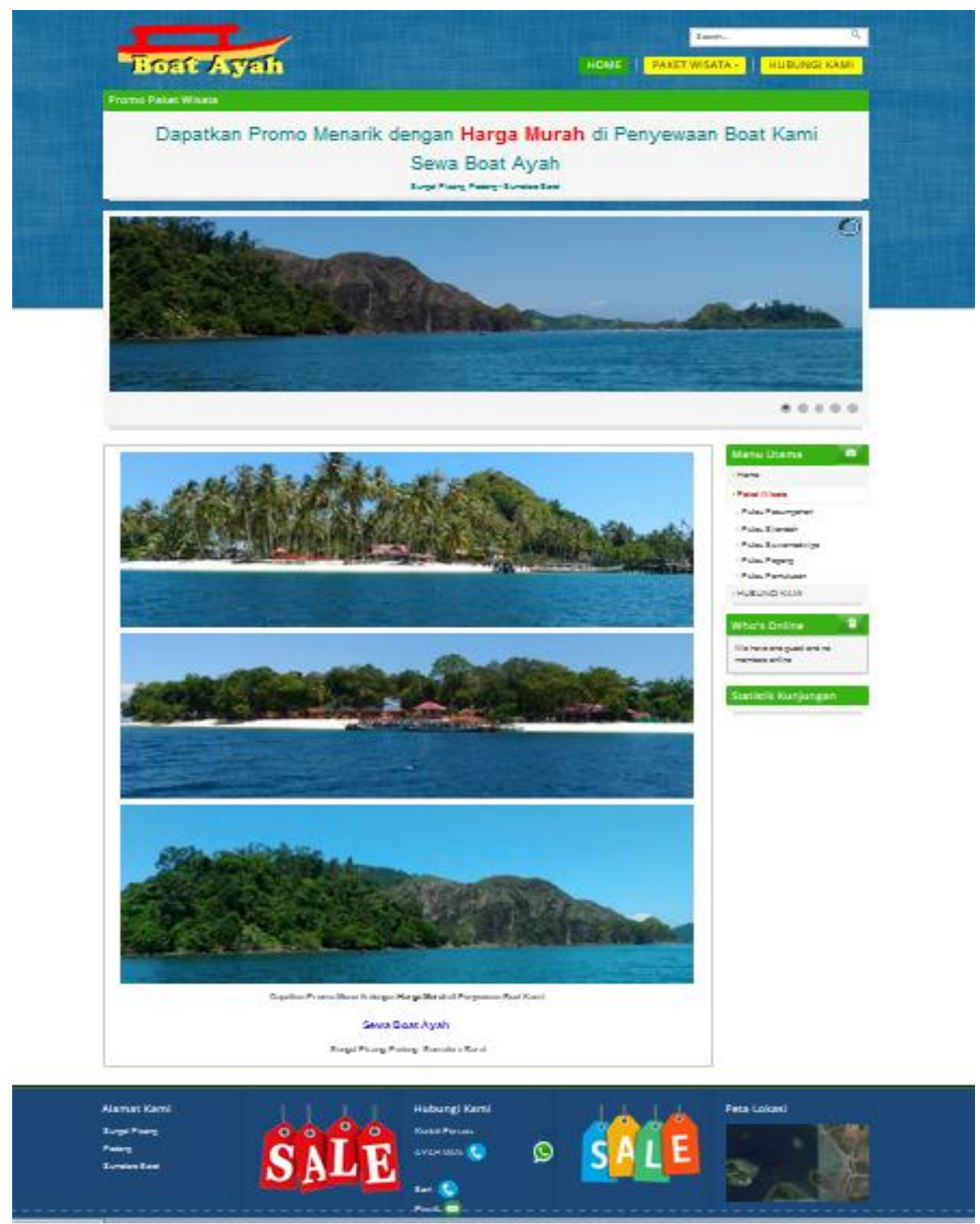

Gambar 4. Tampilan Website 
Sistem informasi pemasaran biduk wisata pulau di Sungai Pisang, Padang, Sumatera Barat ini menawarkan lima paket wisata pulau yang tersedia saat ini yaitu Pulau Pasumpahan, Pulau Sirandah, Pulau Pagang, Pulau Pamutusan, dan Suwarnadwipa. Selain informasi harga paket wisata pulau, sistem informasi pemasaran biduk wisata pulau ini dilengkapi dengan gambar-gambar keindahan masig-masing pulau wisata tersebut untuk menarik pengunjung. Sistem informasi pemasaran ini juga dilengkapi dengan peta lokasi dari google map untuk memudahkan pengguna mencari lokasi pulau wisata yang diinginkan. Setelah mendapatkan informasi tentang wisata pulau yang diinginkan, pengguna dapat menghubungi nelayan biduk melalui nomor kontak yang tersedia baik melalui telpon, sms, maupun email.

\section{Pelatihan Penggunaan Website}

Website yang sudah dirancang kemudian diberikan kepada mitra untuk digunakan sebagai sarana pemasaran produk biduk. Pelatihan diberikan tentang penggunaan website sehingga dapat dijalankan dan dimanfaatkan dengan baik oleh mitra. Selain itu juga diberikan pelatihan pengelolaan website sehingga mitra dapat memanfaatkan website pemasaran biduk tersebut secara berkelanjutan. Mitra sangat antusias dalam pelatihan ini dan menyatakan mendapatkan banyak pengetahuan dalam peningkatan pemasaran biduk mereka. Website ini akan terus digunakan dalam pemasaran biduk sehingga dapat menambah jumlah penumpang dan meningkatkan pendapatan nelayan biduk.
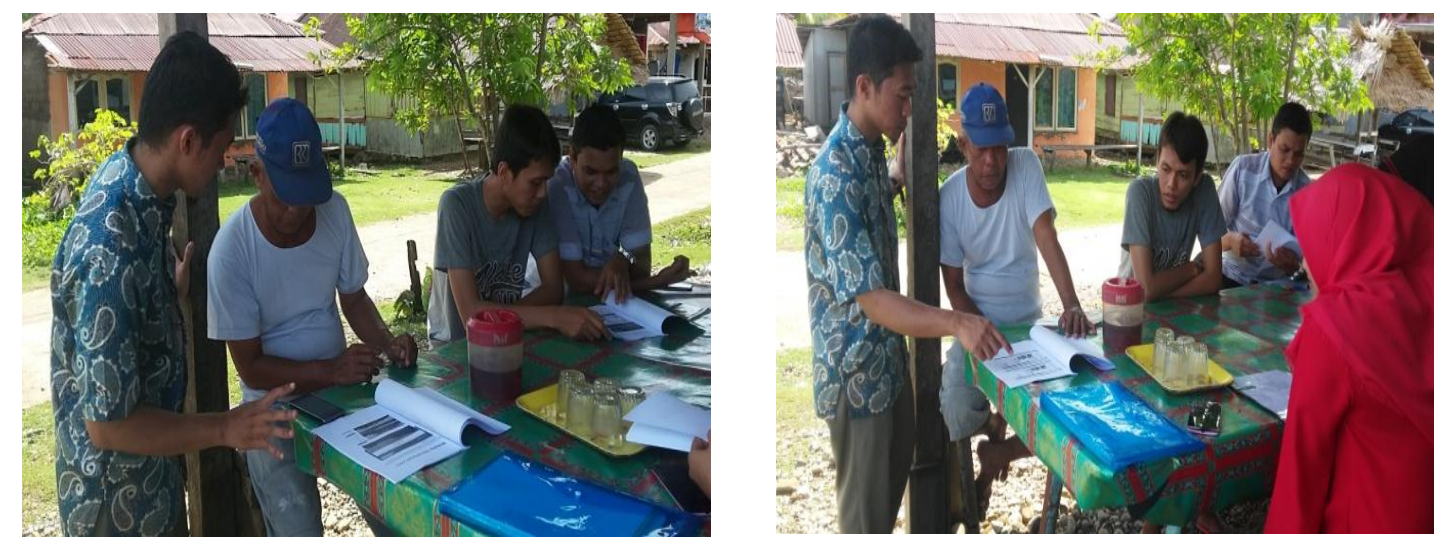

Gambar 5. Pelatihan Penggunaan dan Pengelolaan Website

Berdasarkan informasi yang diperoleh dari mitra setelah menggunakan website ini terjadi peningkatan jumlah penumpang dari sebelumnya. Penumpang biasanya hanya wisatawan yang berada disekitar kota Padang saja. Dengan adanya website ini, mitra telah mendapatkan penumpang dari luar daerah seperti dari Padang Panjang, Bukittinggi, Payakumbuh, dan Batusangkar, bahkan dari luar provinsi seperti Riau, Jambi, dan Lampung. Peningkatan jumlah dan perluasan penumpang merupakan salah satu manfaat yang dapat diperoleh dari pemasaran melalui website, karena informasi biduk wisata pulau dapat diakses dimana saja dan kapan saja oleh semua orang. 


\section{KESIMPULAN DAN SARAN}

Kegiatan peningkatan pemasaran biduk wisata nelayan ini telah dilaksanakan di Sungai Pisang, Bungus Teluk Kabung Selatan, Sumatera Barat. Kegiatan yang dilakukan berupa penyuluhan tentang strategi pemasaran produk yang efektif, perancangan desain biduk yang menarik dan melengkapi biduk dengan fasilitas keselamatan dan kenyamanan penumpang, merancang dan membuat media promosi berupa website pemasaran biduk, dan pelatihan penggunaan dan pengelolaan website. Kegiatan ini telah membantu nelayan biduk dalam meningkatkan jumlah wisatawan pengguna biduk wisata, meningkatkan kepuasan wisatawan terhadap jasa transportasi biduk, dan meningkatkan pengetahuan dan keterampilan kepada nelayan biduk dalam memasarkan biduk wisata pulau sehingga mampu meningkatkan perekonomian nelayan biduk secara berkelanjutan.

\section{UCAPAN TERIMA KASIH}

Penulis mengucapkan terima kasih kepada Direktorat Riset dan Pengabdian Masyarakat, Direktorat Jenderal Penguatan Riset dan Pengembangan, Kementerian Riset, Teknologi dan Pendidikan Tinggi yang telah mendanai kegiatan ini melalui skim Program Kemitraan Masyarakat Nomor: 012/SP2H/PPM/DRPM/2017.

\section{DAFTAR PUSTAKA}

Garvin, D. A. 1988. Managing Quality: The Strategic and Competitive Edge. Harvard Business School.

Kotler, P. dan Keller, K. L. 2009. Manajemen Pemasaran. Edisi 13. Erlangga, Jakarta.

Lovelock, C. dan Wirtz, J. 2011. Service Marketing, People, Technology, Strategy. New Prentice Hall, Upper Sadle River, Jersey.

Sarjulis. 2011. Kehidupan Sosial Ekonomi Masyarakat Nelayan Tanjung Mutiara Kabupaten Agam (1970-2009). Tugas akhir Jurusan Ilmu Sejarah Fakultas Sastra, Universitas Andalas.

Sudarso. 2003. Tekanan Kemiskinan Struktural Komunitas Nelayan Tradisional di Perkotaan. Tugas akhir Jurusan Sosiologi FISIP Universitas Airlangga.

Wasak, M. 2012. Keadaan Sosial Ekonomi Masyarakat Nelayan di Desa Kinabuhutan Kecamatan Likupang Barat Kabupaten Minahasa Utara Provinsi Sulawesi Utara. Pacific Journal. 1(7). 